\title{
A hybrid phytoremediation system for contaminants in groundwater
}

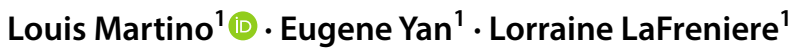

Received: 19 September 2019 / Accepted: 9 November 2019 / Published online: 24 November 2019

(c) The Author(s) 2019

\begin{abstract}
Impacted groundwater at hazardous waste release sites often contain mixtures of contaminants. It can be relatively easy to treat some compounds ex situ. However, mixtures of some compounds can be difficult to treat. A method to extract and treat complex mixtures of contaminants of concern using phytotechnology is proposed in this paper. A specific case study is described wherein a hybrid phytoremediation system is compared and contrasted with conventional groundwater and phytoremediation technologies. Nitrate is used as an exemplar co-contaminant since nitrate contamination is (1) widespread in the United States, and (2) difficult and expensive to treat. The approach involves using contaminated groundwater as a source of irrigation water for a phytoremediation grove. Groundwater would be extracted using conventional groundwater extraction methods. Groundwater then would be pumped to multiple irrigation zones under the control of an autonomous irrigation system. Each zone would consist of a number of trees. The root system for each tree would be modified to function as a confined treatment cell that facilitates contaminated water uptake. The irrigation controller would optimize the amount of groundwater that can be extracted and treated while preventing surface water runoff away from the phyto component.
\end{abstract}

Keywords Phytoremediation · Mixture of contaminants $\cdot$ Pump and treat $\cdot$ Controlled irrigation $\cdot$ Groundwater

\section{Introduction}

The cleanup of sites such as those at Superfund, Resource Conservation and Recovery Act (RCRA) corrective action, and underground storage tank release sites often requires linking feasible treatment technologies with the COCs present at the site. For the sake of discussion, COCs can be categorized into contaminant groups as follows:

- Nonhalogenated volatile organic compounds (VOCs),

- Halogenated VOCs,

- Nonhalogenated semi-volatile organic compounds (SVOCs),

- Halogenated SVOCs,

- Fuels,

- Inorganics,

- Radionuclides, and

- Explosives (FRTR 2002).

Louis Martino

martinol@anl.gov

1 Environmental Science Division, Argonne National Laboratory, 9700 South Cass Avenue, Lemont, IL 60439-4843, USA
A treatment technology may be well suited to treat one or several of the contaminant groups. However, typically no single technology can address all of the contaminant groups noted.

In the Midwestern United States, an agricultural region, one of the halogenated VOCs, carbon tetrachloride, was in widespread use as a state-of-the-art fumigant for grain preservation throughout the 1950s and 1960s. Entering the environment either because of spillage or methods of application, the fumigant migrated through the near-surface and unsaturated vadose zone soils into groundwater. Removal of carbon tetrachloride from impacted groundwater can be implemented by groundwater extraction followed by ex situ treatment. However, in this agricultural region, groundwater is commonly contaminated with nitrate as a non-point source due to legacy agricultural practices. The technologies suitable for treating halogenated VOCs cannot be used to treat nitrates, a $\mathrm{COC}$ in the inorganics contaminant group. Addressing COCs in both the halogenated VOC and inorganics contaminant groups requires combining treatment technologies to achieve remedial action goals such as a desired cleanup concentration threshold in groundwater or a performance threshold such as the amount of COC removal over time. The current limitation of combined treatment technologies poses a significant 
challenge as well as an economic barrier to removing carbon tetrachloride in a cost-effective way.

Phytoremediation has received much attention due to its ability to use multiple contaminant removal mechanisms with significant benefits over conventional in situ and ex situ treatment systems that include ecological enhancement, aesthetic value, low operations and maintenance (O\&M) costs (because the systems are self-sustaining), and both public and regulatory approval. However, phytoremediation suffers several limitations: (1) contaminated groundwater usually exceeds the 25 feet $(\mathrm{ft})[7.6$ meters $(\mathrm{m})]$ below ground surface (bgs) threshold for effective vertical tree root growth; (2) expiration is often not optimal because of less effective groundwater extraction through the tree root system; and (3) the need to place the phytoremediation component immediately above the contaminated groundwater undergoing remediation could make implementation difficult because of other surface land uses. In this study, we propose a hybrid phytoremediation system that combines an optimally controlled in situ plant treatment system with an active groundwater extraction system to expand the phytoremediation's capacity beyond its limitations of shallow depth, low expiration, and placement vis-a-vis contaminated groundwater, while treating both a halogenated VOC (e.g., carbon tetrachloride) and an inorganic nutrient (e.g., nitrate).

The following section provides an overview of phytoremediation. Following that are sections that discuss the mainstream technologies used to extract and treat groundwater contaminated with halogenated VOCs and provide background on the presence of nitrate in groundwater and on nitrate treatment technologies. We then discuss our approach for treating contaminant mixtures using a proposed hybrid phytoremediation system and present a sample design case study for the proposed system at a former grain storage site in the Midwest. The design case presented provides the technical basis and design guidance for remediating multiple COCs. The benefits of the design case relative to other treatment methods are discussed and summarized in the last sections.

\section{Phytoremediation review}

\section{What is phytoremediation?}

For this paper, phytoremediation is defined as the remediation of environmental media (surface water, groundwater, soil) using plants. Phytoremediation is performed through a number of processes, working singly or in combination. These processes and their associated mechanisms are as follows:

- Phytosequestration - the sequestration of contaminants in the rhizosphere;
- Rhizodegradation - the biodegradation of contaminants in the rhizosphere;

- Phytohydraulics - the capture and evapotranspiration of water;

- Phytoextraction - the capture and evapotranspiration of contaminants;

- Phytodegradation - the breakdown of contaminants being transpired by the plant; and

- Phytovolatilization - the transpiration of VOCs taken up by the plant (ITRC 2009).

The applicability and performance of phytoremediation are strongly dependent on the characteristics of the site. Since highly concentrated contaminants can be toxic to plants, phytoremediation is often used at sites with low concentrations of contaminants or as a final polishing step. Nevertheless, compared to conventional remediation technologies, phytoremediation approaches tend to require lower initial construction costs and a smaller energy footprint. Since plants are the focal point of the technology, phytoremediation has an appeal as a low technology, environmentfriendly "green" solution. Plants can improve the visual appearance of a site, supplement existing habitat, and create a land reuse/restoration asset. Unlike typical pump and treat remedies where groundwater is extracted, treated, and discharged to surface water, phytoremediation approaches do not create a water waste stream. Taken together, these advantages foster public acceptance and can give a project the cache of good environmental stewardship (USEPA 2010).

Some site characteristics, however, preclude the use of a phytoremediation approach. For example, phytoremediation may be inappropriate for sites with concentrated, phytotoxic contaminants and for sites with contaminants present at depths beyond the reach of natural plant (tree) roots. The time-frame of phytoremediation tends to be longer than traditional cleanup technologies; therefore, requirements to sample and analyze plant tissue, plant characteristics, and environmental media (soil, groundwater, etc.) over that extended time-frame can result in significant O\&M costs. In some cases, risk analysis may be required to evaluate the migration pathways such as the way contaminants (especially inorganic constituents) could be bioaccumulated in food webs and the way harvested plant material that may contain contaminant residuals are handled. In addition, the aerial footprint required to implement phytoremediation can be much greater than that of traditional technologies (USEPA 2010).

The combined irrigation/phytoremediation approach discussed in this paper necessitates the consideration of additional issues. The design and operating practices and cautions associated with the land treatment of municipal wastewater effluents are relevant (USEPA 2006). When using irrigation to treat wastewater (in this case contaminated 
groundwater) one needs to be cognizant of the concept of the limiting design parameter (LDP) for the treatment of the wastewater source; that is the factors or parameters that control the design and operation of the phytoremediation/ irrigation system. One would need to evaluate whether water quality is suitable for ongoing irrigation including ensuring that the nutrient mix and sodium adsorption ratio (SAR) is adequate (or can be otherwise adjusted by additives or additional make-up water) so that plant growth is optimized; irrigation practices do not cause damage to soil structure; and to ensure that constituents in the irrigation water would not accumulate to phytotoxic levels.

\section{Phytoremediation examples}

Phytoremediation has been deployed at numerous sites throughout the United States (USEPA 2005). A recent search of the U.S. Environmental Protection Agency's (USEPA's) Contaminated Site Clean-up Information (CLU-IN) database for sites involving the remediation of all environmental media and all plant types found 92 examples of ongoing field-scale or full-scale phytoremediation projects in the United States and 12 other countries (USEPA 2016). A search for the remediation of groundwater only found ongoing field-scale or full-scale phytoremediation projects at 60 sites using 301 vegetation types (both woody and herbaceous types). The results of a more focused search for sites involving the remediation of groundwater using only tree species (as noted) are in Table 1. Table 2 summarizes the phytoremediation mechanism and COCs being targeted for these sites. As noted in Table 2, phytoremediation is being used in several cases to treat a complex mixture of one or more contaminants (USEPA 2016).

In general, herbaceous species such as grasses and forbes have rooting depths between 1 and $2 \mathrm{ft}(0.3-0.6 \mathrm{~m})$. Prairie grasses can achieve depths of 10-15 ft (3.0-4.6 m) Trees also can achieve depths of 10-15 ft (3.0-4.6 m) if special planting practices are used. Although herbaceous species can be used, trees are more often relied on to address groundwater contamination. Trees are favored because their rooting depths and water (uptake) requirements (five to 10 gallons/tree/day) [18.9-37.8 L/tree/day] allow for the treatment of significant amounts of contaminated groundwater, especially if trees are planted in large groves. Laboratory and controlled field studies have indicated that dissolved halogenated VOCs can be degraded via microbial metabolism in the rhizosphere or root zone of trees (Anderson et al. 1993; Anderson and Walton 1995; Newman et al. 1997, 1999; Brigmon et al. 1999), mineralized through plant metabolic activities in the transpiration stream after uptake (Wang et al. 2004), or removed through rapid dispersion from plants into the atmosphere (Davis et al. 1999; USEPA 2010).

In general, the maximum practical depth that can be achieved using specialized planting practices is $25 \mathrm{ft}(7.6 \mathrm{~m})$ bgs (ITRC 2009).

\section{Factors influencing phytoremediation of groundwater}

Several factors have a strong influence on the efficacy of phytoremediation approaches, including contaminant type and concentration, contaminant depth, soil type, and climate. To some extent, soil type and climate can be engineered with irrigation approaches, soil additives, and planting techniques. Addressing contaminant-specific issues (type, concentration, and depth) is more problematic.

The maximum depth of contamination that can be targeted is generally $25 \mathrm{ft}$ (7.6 m) bgs (ITRC 2009). To achieve this rooting depth, specialized planting techniques are necessary to extend root growth. Deep-rooting phreatophytes such as poplar and willow species or hybrids can be used very effectively. These candidate species are planted in
Table 1 Tree species or types used to remediate groundwater contamination. Source: USEPA (2016)

\begin{tabular}{lll}
\hline Apple & English oak & Native willow \\
Ash & Eucalyptus & Niobe weeping willow \\
Bald cypress & European ash & Norway maple \\
Black alder & Hardwoods & Peach \\
Black hills spruce & Hybrid poplars & Pin oak \\
Black willow & Hybrid poplar (clone 184-411) & Swamp white oak \\
Conifers & Hybrid poplar (clone OP-367) & Poplar \\
Cottonwoods & Laurel leaf willow & River birch \\
Coyote willow & Live oak & Russian olive \\
Eastern redbud & Loblolly pine & Saltcedar \\
Cedar & Magnolia & Silver maple \\
Pine & Maples & Siouxland poplar \\
Eastern white pine & Narrowleaf willow & Sweetgum \\
Elm & Native cottonwood & \\
\hline
\end{tabular}




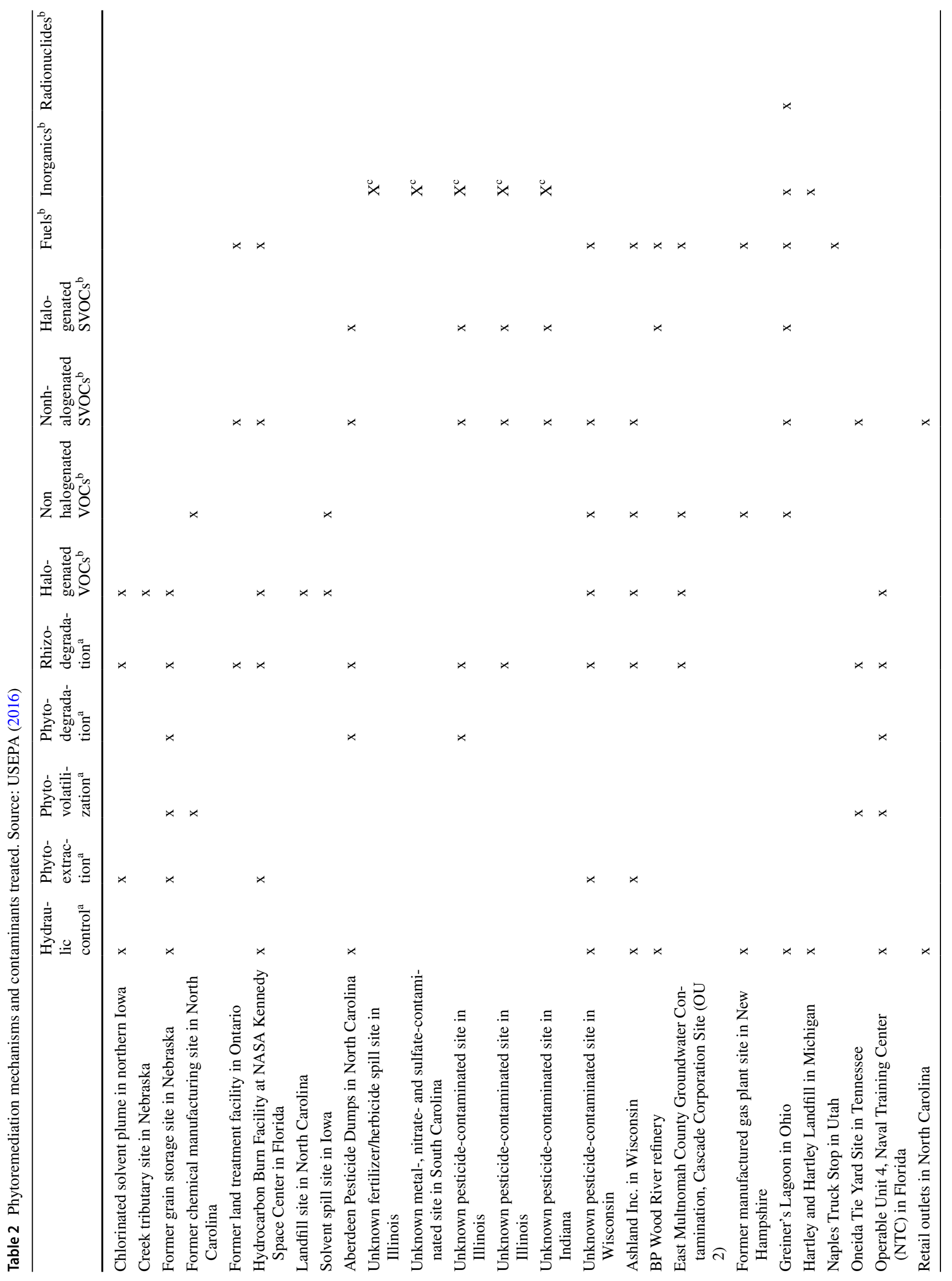




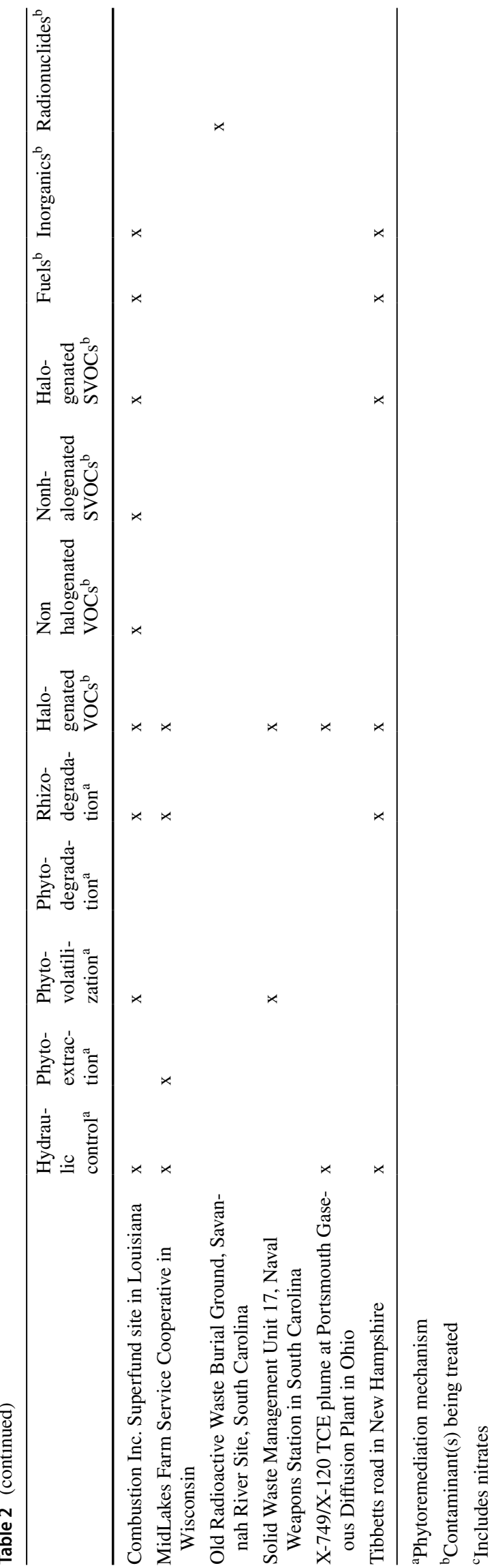

specially constructed borings with modifications such as aeration tubes to mimic the natural atmospheric condition of a near-surface rhizosphere. In addition, a design to force the specially planted trees to use water from the targeted remediation zone in lieu of using near-surface groundwater must be maintained.

At the Murdock, Nebraska, site, a subset of the 2000 trees in the phytoremediation grove (representing six species: Niobe Weeping Willow, Black willow, Eastern cottonwood, hybrid poplar, Green Ash, and Northern catalpa) are planted where the static groundwater level is typically more than 4-5 ft (1.2-1.5 m) bgs. Initially, soil borings as deep as $12 \mathrm{ft}$ $(3.7 \mathrm{~m})$ were used to plant a number of trees. The TreeWell ${ }^{\circledR}$ design used at the Murdock site consisted of 24-inch (in.) $(0.6 \mathrm{~m})$-diameter boreholes lined with plastic sleeves meant to limit access to shallow soil water and to force root growth downward to optimize the uptake of deeper contaminated groundwater, as shown in Fig. 1 (Argonne 2009).

\section{Phytoremediation, a single technology for treating multiple contaminants}

A key factor influencing whether or not phytoremediation can be used at a site is the COC or mix of COC groups that must be remediated. Ex situ cleanup technologies are typically well-suited to treat a single COC or, at best, mixtures of COCs that can be degraded with similar physical, chemical, or biologic processes. However, in some cases multiple treatment steps and technology types are needed to address a diversity of COC groups. As the number of treatment steps and technology types increases, project complexity, capitol costs, and O\&M costs also increase. In contrast, phytoremediation, a single treatment method, can be used to address complex COC mixtures that would otherwise require multiple treatment technologies.

As noted in Table 2 and documented elsewhere in the literature, phytoremediation can be used to treat petroleum hydrocarbons, gas condensates, crude oil, chlorinated compounds, pesticides, and explosive compounds, as well as inorganic contaminants including salts (salinity), heavy metals, metalloids, and radioactive materials (ITRC 2009). Sites have used phytoremediation to address complex COC mixtures involving constituents with a disparate chemical make-up (e.g., organic and inorganic constituents, or volatile and non-volatile constituents).

\section{Carbon tetrachloride background and remediation technologies}

Carbon tetrachloride was commonly used as a grain fumigant or as a component in grain fumigant formulations in the Midwest. Although usage as a grain fumigant has ceased as 


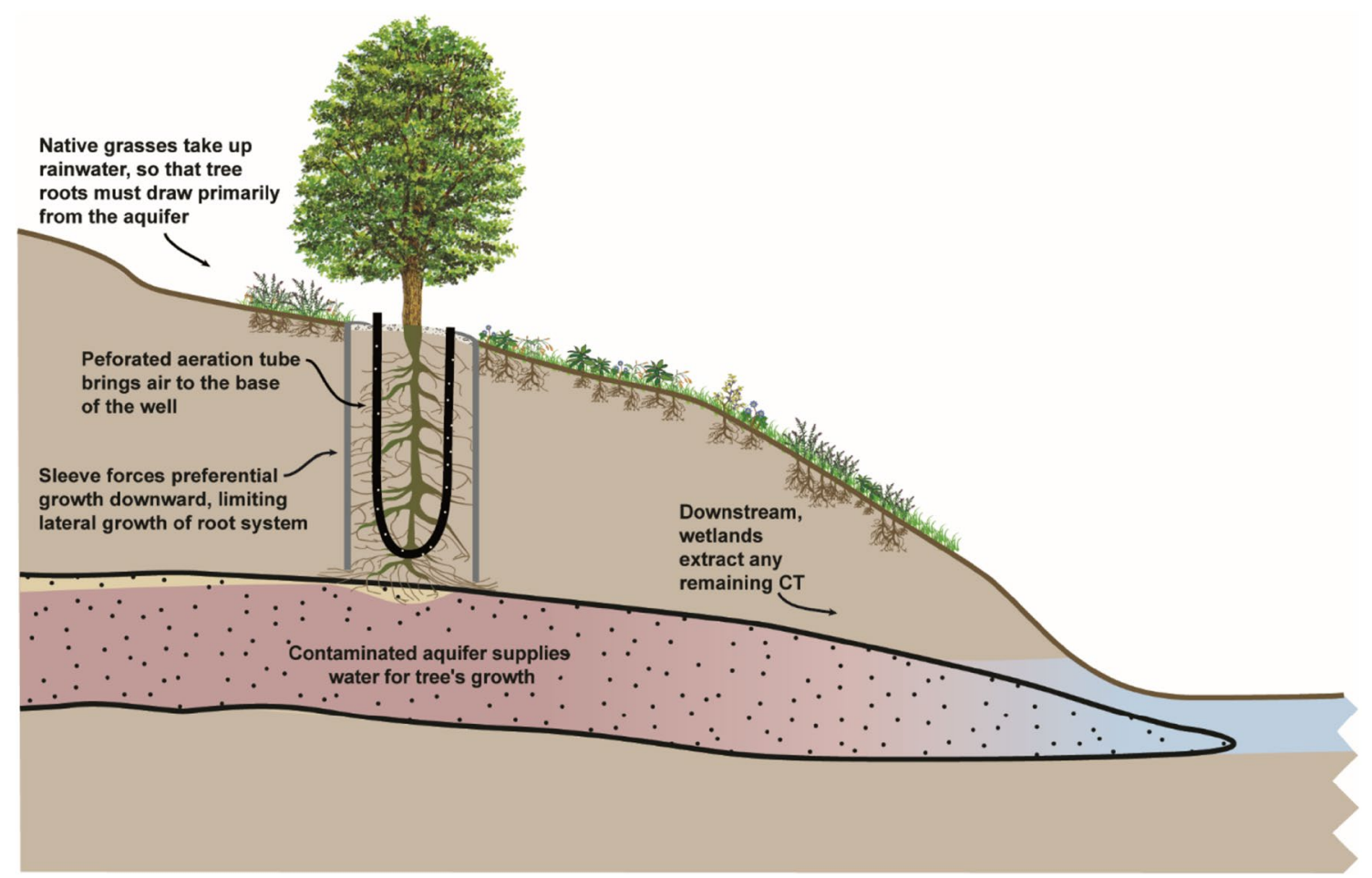

Fig. 1 Schematic of the TreeWell ${ }^{\circledR}$ design used at the Murdock, Kansas, site

of about 1986, sites impacted by legacy carbon tetrachloride use have been found in multiple agricultural states including Kansas, Nebraska, Missouri, Iowa, and Colorado (Misiorowski and Eagle 2007). The maximum contaminant level (MCL) for carbon tetrachloride in drinking water is 5 microgram per liter $(\mu \mathrm{g} / \mathrm{L})$. The presence of carbon tetrachloride above the regulatory threshold necessitates the replacement of the contaminated groundwater with an alternate water supply source and the possible regulator-imposed remediation of contaminated groundwater to achieve levels at or less than the MCL.

Groundwater contaminated with carbon tetrachloride can be remediated by in situ or ex situ methods. This discussion focuses on ex situ methods. Ex situ treatment of contaminated groundwater requires a groundwater extraction component and a treatment component. Groundwater extracted from impacted portions of an aquifer would require treatment to remove COCs such as carbon tetrachloride. Suitable treatment technologies include carbon adsorption or air stripping.

Carbon adsorption systems consist of beds or cartridges of activated carbon [granular activated charcoal (GAC) unit]. These systems are frequently used as a final polishing step for drinking water treatment. Organic compounds, such as synthetic organic chemicals (and those affecting groundwater taste and odor), are adsorbed by the carbon media. Air stripping, the most relevant treatment technology, involves the transfer of VOCs from water to air. For dilute concentrations of VOCs, the process is typically conducted in a system like a packed tower scrubber or a tray aerator.

Tray aerators work on the same principles as packed tower scrubbers except that the treatment media is spread out on several perforated trays that can be stacked vertically in series. Water is sprayed onto the top tray and a blower circulates air through the treatment media positioned on the trays. Typically, tray aerators offer the advantage of a smaller vertical footprint than packed tower scrubbers. Air and water effluents from packed tower scrubbers can be treated in the same fashion as effluent from tray aerators. Treated groundwater can be discharged to surface water with regulatory approval.

\section{Nitrate background and remediation technologies}

\section{Nitrate contamination in the United States}

Nitrate contamination in groundwater is problematic throughout the United States, impacting both public water supply systems and privately owned water supply wells. The contamination is so widespread and serious it has been called "Rural America's Own Private Flint," a reference to the water supply issues that came to light in Flint, 
Michigan (Healy 2018). The USGS determined that about 43 million Americans rely on private wells as a water supply source (DiSimone et al. 2014). Extrapolating based on data from the U.S. Census web site, potentially 49 million Americans rely on private wells, as of February 2019 (US Census Bureau 2019). Estimates of private well usage for each state are shown in Fig. 2. Also shown for each state is the aerial extent of groundwater nitrate concentrations exceeding 5 milligrams per liter $(\mathrm{mg} / \mathrm{L})$, half the value of the MCL, revealing that in some cases, more than $9 \%$ of the aerial extent of several states have groundwater nitrate concentrations greater than $5 \mathrm{mg} / \mathrm{L}$. These states include
Delaware, Maryland, Nebraska, Rhode Island, Louisiana, Massachusetts, Arizona, and California.

Figure 2 shows that nitrate contamination issues are relevant throughout the United States. In many states where nitrate contamination is prevalent, residents rely on self-supplied drinking water sources, which in most cases consist of privately installed water supply wells. Nitrate concentrations in groundwater are dependent on aquifer characteristics. Domestic water supply wells are frequently installed in the upper portion of the aquifer because shallow groundwater is "younger" than deeper groundwater and its quality reflects more recent (i.e., less) nutrient
Fig. 2 Percentages of population with self-supplied drinking water (by state) and state area with nitrate levels greater than $5 \mathrm{mg} / \mathrm{L}$; there are no data for Hawaii or Alaska (USEPA 2019) (generated using Microsoft Excel)

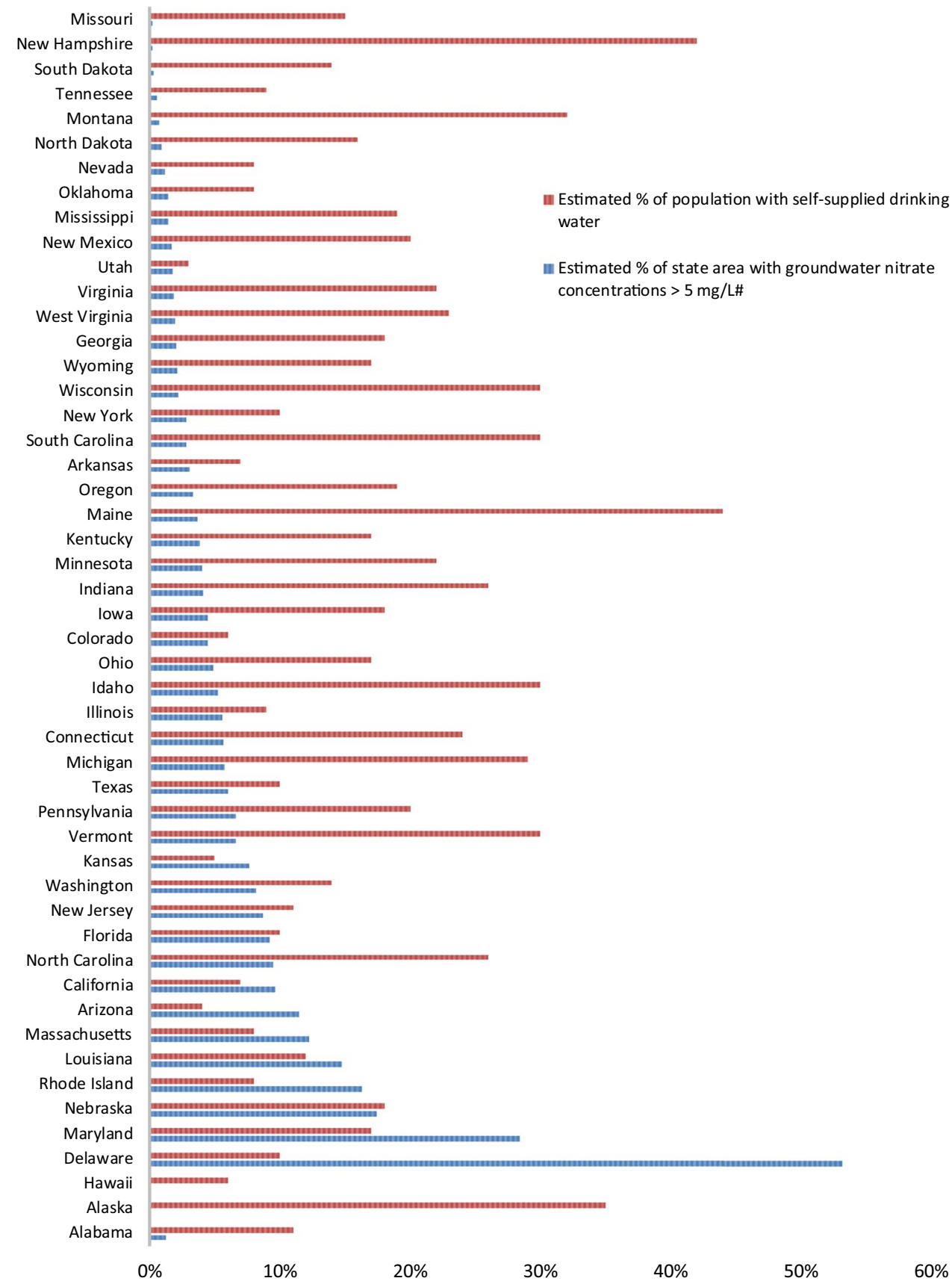


inputs and better land management practices (Dubrovsky et al. 2010).

\section{Overview of nitrate treatment approaches}

Ion exchange and reverse osmosis are two of the more commonly used nitrate removal technologies. Both of these technologies are feasible for municipal applications [with flow rates of 0.5 million gallons $(1,892,705.9 \mathrm{~L})$ per day], but they have high capital and O\&M costs for the treatment capacity (both flow rate and volume) needed. For a singleresidence system with a relatively low, intermittent flow rate, reverse osmosis is a commonly used, cost-effective technology. However, neither technology is suitable for flow rates between that of a municipal system and a single residence. In some cases, the volume of water produced by a groundwater extraction system would be significantly less than the inflow for a municipal system, but much larger than the inflow for a single-residence system (Jacobs and Davis 2011; Davis and Jacobs 2012). Even after turbidity control and ion exchange, reverse osmosis is still sometimes required as a polishing step.

The most commonly used ex situ active treatment approach for nitrate is ion exchange. This technology can remove high concentrations of nitrate, is considered reliable, has a minimal footprint, is easy to operate, and has the least capital costs of the typically used technologies. However, because of the presence of ions that have chemical properties similar to nitrate in groundwater, this approach requires a high ion exchange capacity, which can be prohibitively costly to operate. Key factors affecting the feasibility and cost of ion exchange include pretreatment requirements, the need for resin replacement, the frequency of system backwash, and residual waste management. In some cases, pretreatment steps can include turbidity removal and cation exchange upstream of the anion exchange system (the ion resin that treats nitrate). Backwashing of resins, whether anion or cation exchange resins, generates a brine waste stream that must be disposed of on-site, transported to an off-site treatment/handling location, discharged to a publicly owned treatment works, or otherwise discharged to surface water (with regulatory approval). Treatment of resins is required prior to controlled disposal.

Both the capital and O\&M costs for ion exchange and reverse osmosis systems can be significant. The cost per person per year to construct and operate an ion exchange system has been estimated to range from $\$ 90$ to $\$ 666$ for small scale systems (with less than 501 users) and from $\$ 48$ to $\$ 273$ for medium size systems (with 3301 to 10,000 users) (Schechinger and Cox 2018).

Passive technologies for the treatment of water include wood chip bioreactors and constructed wetlands, also known as "surface flow wetlands" and "subsurface flow wetlands"
(ITRC 2003; Jasper et al. 2014; USDA 2009). Constructed wetlands can treat contaminants by both abiotic (settling, sedimentation, sorption, chemical oxidation/reduction, precipitation, photodegradation and oxidation, and volatilization) and biotic mechanisms that include phytoremediationrelated processes (anaerobic and aerobic, biodegradation, phytoaccumulation/phytostabilization, phytodegradation/ rhizodegradation, and phytovolatilization/evapotranspiration) (ITRC 2003). Typically, these systems are designed to receive and treat nitrate contaminated irrigation water by gravity flow from impacted sources to the passive treatment systems. However, passive systems may not function well year-round.

A drawback for both the active and passive nitrate treatment systems is that they require the discharge of treatment residuals and/or treated water to surface water. In most states, discharges to surface water are strictly regulated and must meet rigorous discharge standards, including, in some cases, drinking water MCLs.

\section{A case study for remediating contaminant mixtures in groundwater}

This paper presents a site-specific case study to compare and contrast a mainstream ex situ treatment approach to a less conventional groundwater remediation approach. In this case study, the challenge for the remedial project team is to evaluate cost-effective remedial alternatives that can address contaminants in two different contaminant groups: carbon tetrachloride (a chlorinated VOC) and nitrate (an inorganic). At the site in question, carbon tetrachloride is present in groundwater due to a release resulting from the past application of fumigants; nitrate is also present. Both contaminants occur at concentrations above the drinking water MCL. The issues associated with remediating both contaminants at the site provide the basis for the case study.

\section{Understanding the nature, extent, and magnitude of contamination at the case study site}

The site is a former CCC/USDA facility located in an agricultural area in Kansas where fumigants containing carbon tetrachloride were used in a grain storage facility operated from 1954 to 1966. Carbon tetrachloride has been detected in groundwater at concentrations above the USEPA drinking water MCL and the state of Kansas' Tier 2 risk-based screening level (RBSL) for drinking water $(5.0 \mu \mathrm{g} / \mathrm{L})$. Three groundwater bearing zones were identified in the bedrock shale formation at the site: (1) a top thin perched aquifer [2-3 ft (0.6-0.9 m) thick] at depths of 20-30 ft (6.0-9.0 m), (2) a shallow aquifer (4-19 $\mathrm{ft}(1.2-5.8 \mathrm{~m})$ thick) at depths of 35-46 ft (10.7-14.0 m), and (3) a deep aquifer [ $>35 \mathrm{ft}$ 
$(10.7 \mathrm{~m})$ thick] below a depth of $55 \mathrm{ft}(16.8 \mathrm{~m})$. The vertical relationship and locations of the three groundwaterbearing zones are shown in Fig. 3. Carbon tetrachloride was detected at concentrations up to $131 \mu \mathrm{g} / \mathrm{L}$ in the perched aquifer located in the central and southern parts of the case study site (Fig. 4). The underlying shallow aquifer was also

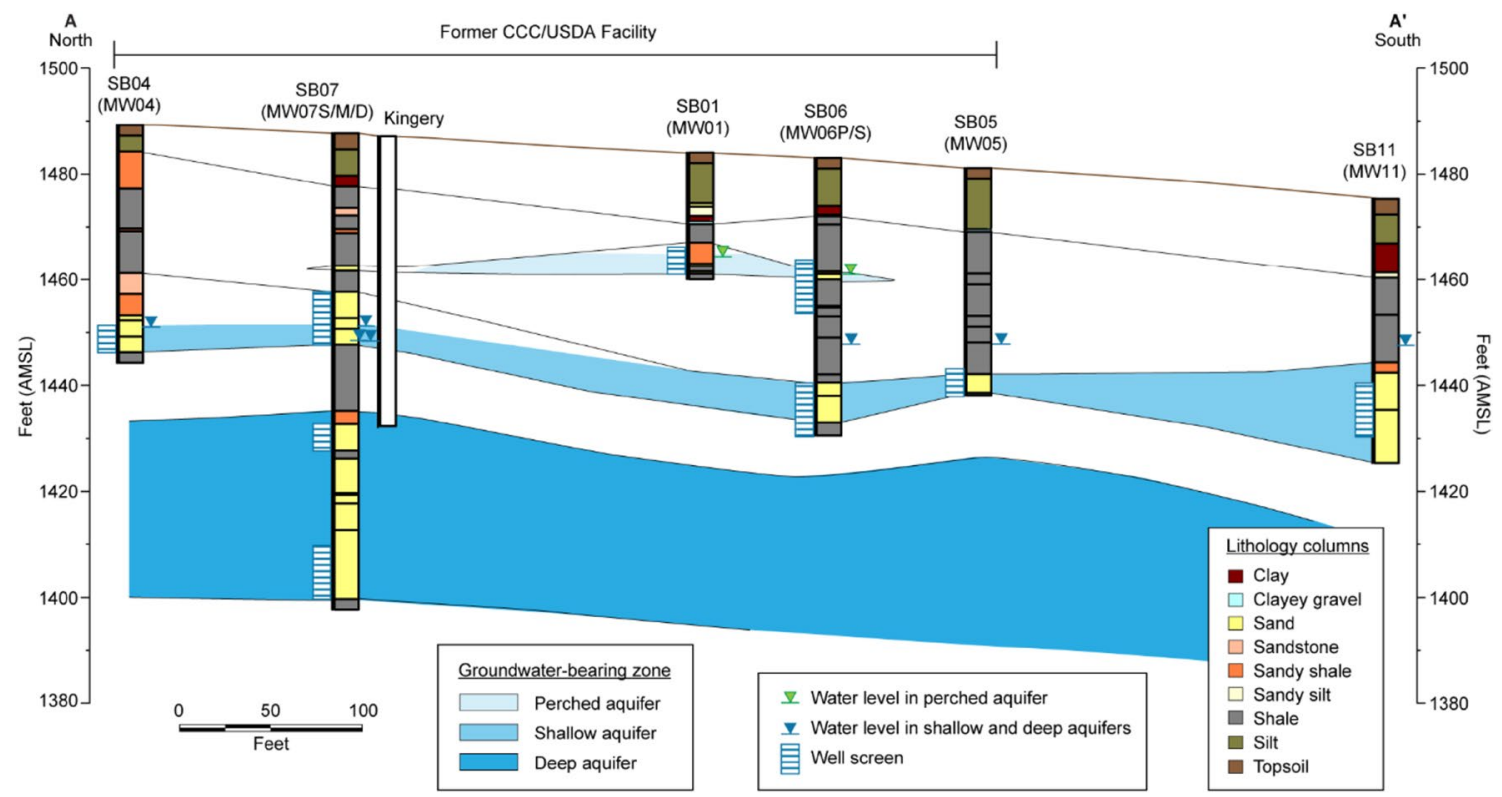

Fig. 3 Stratigraphic cross section showing groundwater-bearing zones beneath the former CCC/USDA facility (AMSL above mean sea level; map location of $A-A^{\prime}$ is shown in Fig. 6)

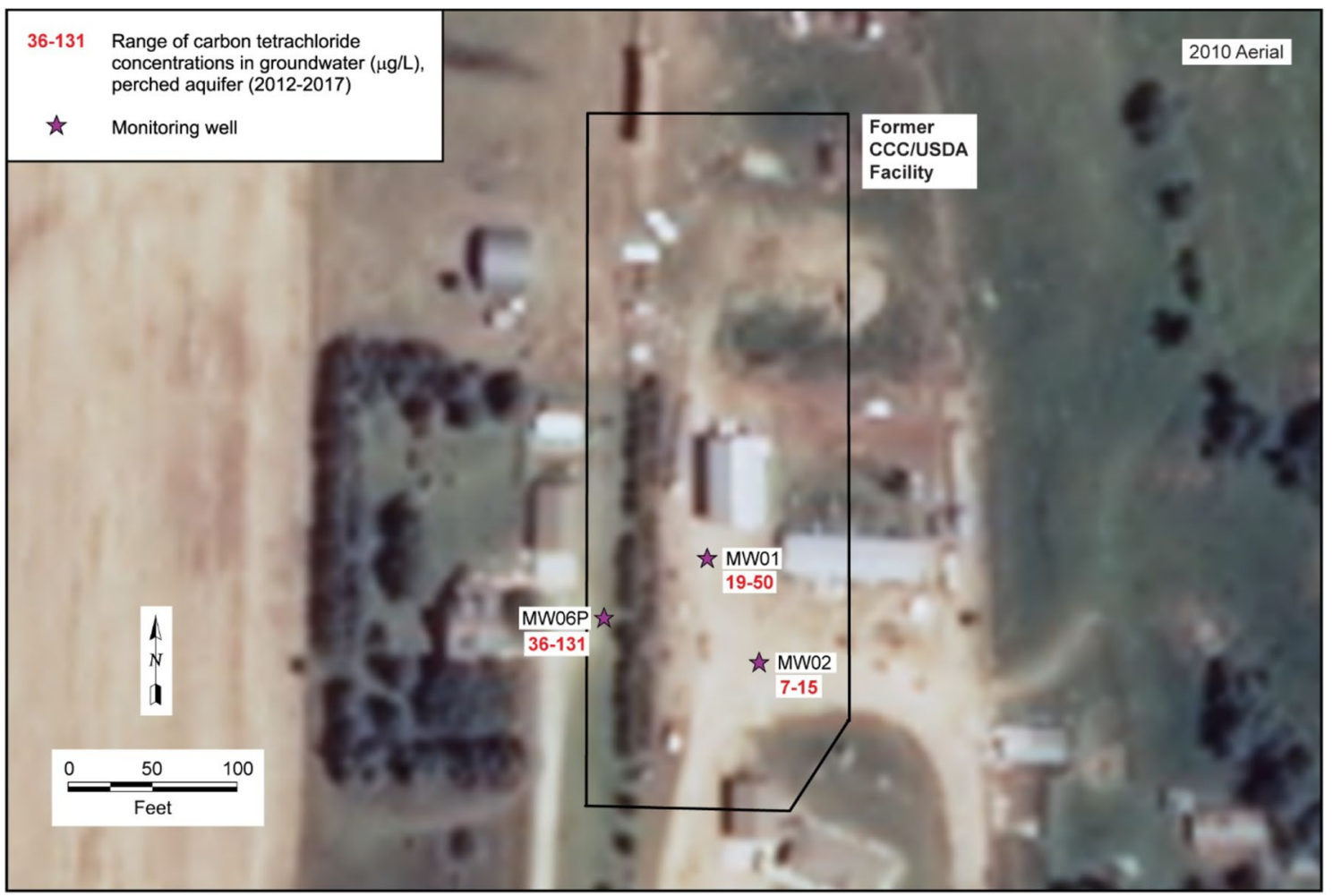

Fig. 4 Carbon tetrachloride concentrations in the perched aquifer at the former CCC/USDA facility 
found to be contaminated with carbon tetrachloride, at the concentrations up to $105 \mu \mathrm{g} / \mathrm{L}$ (Fig. 5).

Based on results of slug tests for all monitoring wells, hydraulic conductivity within the contaminated area is relatively low: about $0.11-0.26 \mathrm{ft}$ per day (ft/day) $(0.03-0.08 \mathrm{~m} /$ day) for the perched aquifer and $2.57-5.47 \mathrm{ft} / \mathrm{day}(0.8-1.7 \mathrm{~m} /$ day) for the shallow aquifer. The extent of the perched aquifer is limited within the site. The distribution of contaminants also supports the evidence that there has been limited migration of contaminants in the shallow aquifer over the 46 year period between the termination of grain storage activities and current investigation activities. The deep aquifer was not found to be contaminated and no vertical migration from the shallow aquifer to the deep aquifer has been detected. Overall, the carbon tetrachloride contamination is limited vertically to the perched and shallow aquifers and laterally within the footprint of the case study site.

Nitrate has also been detected at concentrations of $93-340 \mathrm{mg} / \mathrm{L}$ in monitoring and private wells located on or near the site (Fig. 6), far exceeding the drinking water MCL and state of Kansas' RBSL for this contaminant. The nitrate contamination in these wells is unrelated to grain storage activities performed during the term of the CCC/USDA lease (Fig. 6). In addition, analyses for major ions in groundwater in the perched and shallow aquifers also show poor water quality with a total hardness of $1637-1923 \mathrm{mg} / \mathrm{L}\left(\mathrm{CaCO}_{3}\right)$ and total dissolved solids (TDS) of 3146-3643 mg/L. These factors add additional challenges to ex situ treatment and disposal of the high volume waste stream generated by most of the available treatment methods.

\section{Site-specific groundwater remediation goals}

The site-specific goals of any proposed remedial action at the case study site concern groundwater. These goals are to:

- Reduce the concentration, mass, and volume of contaminants in the perched aquifer to eliminate the migration pathway from the perched aquifer to the shallow aquifer; and

- Reduce the level of groundwater contamination in the shallow aquifer to prevent any further lateral and vertical migration beyond the current extent of contamination in the shallow aquifer.

\section{Effectiveness of groundwater extraction and treatment}

Groundwater extraction and treatment would result in permanent reduction in the mobility and volume of the dissolved carbon tetrachloride contamination. Based on the results of slug tests and hydraulic analysis, the potential

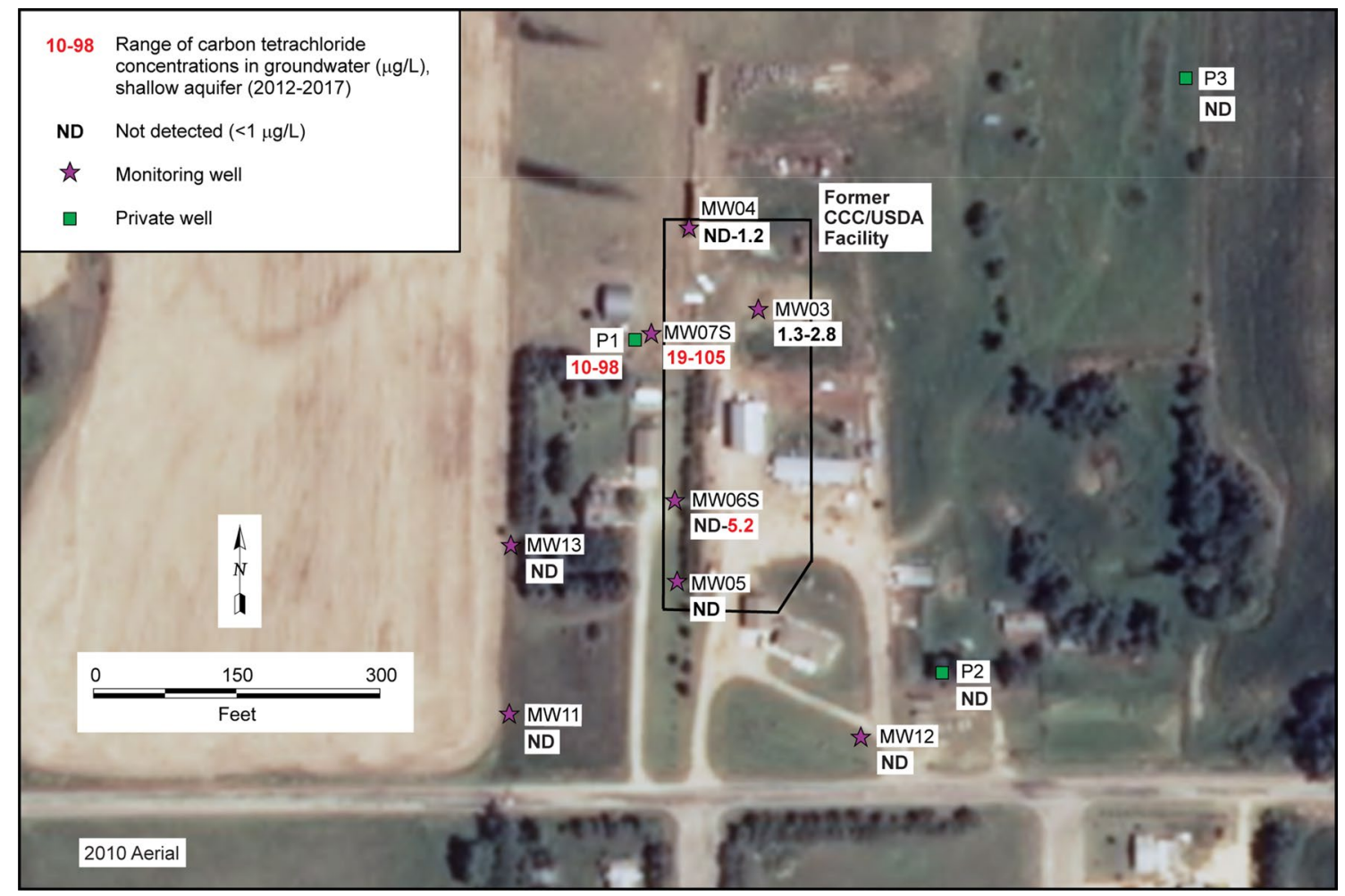

Fig. 5 Carbon tetrachloride concentrations in the shallow aquifer at the former CCC/USDA facility 


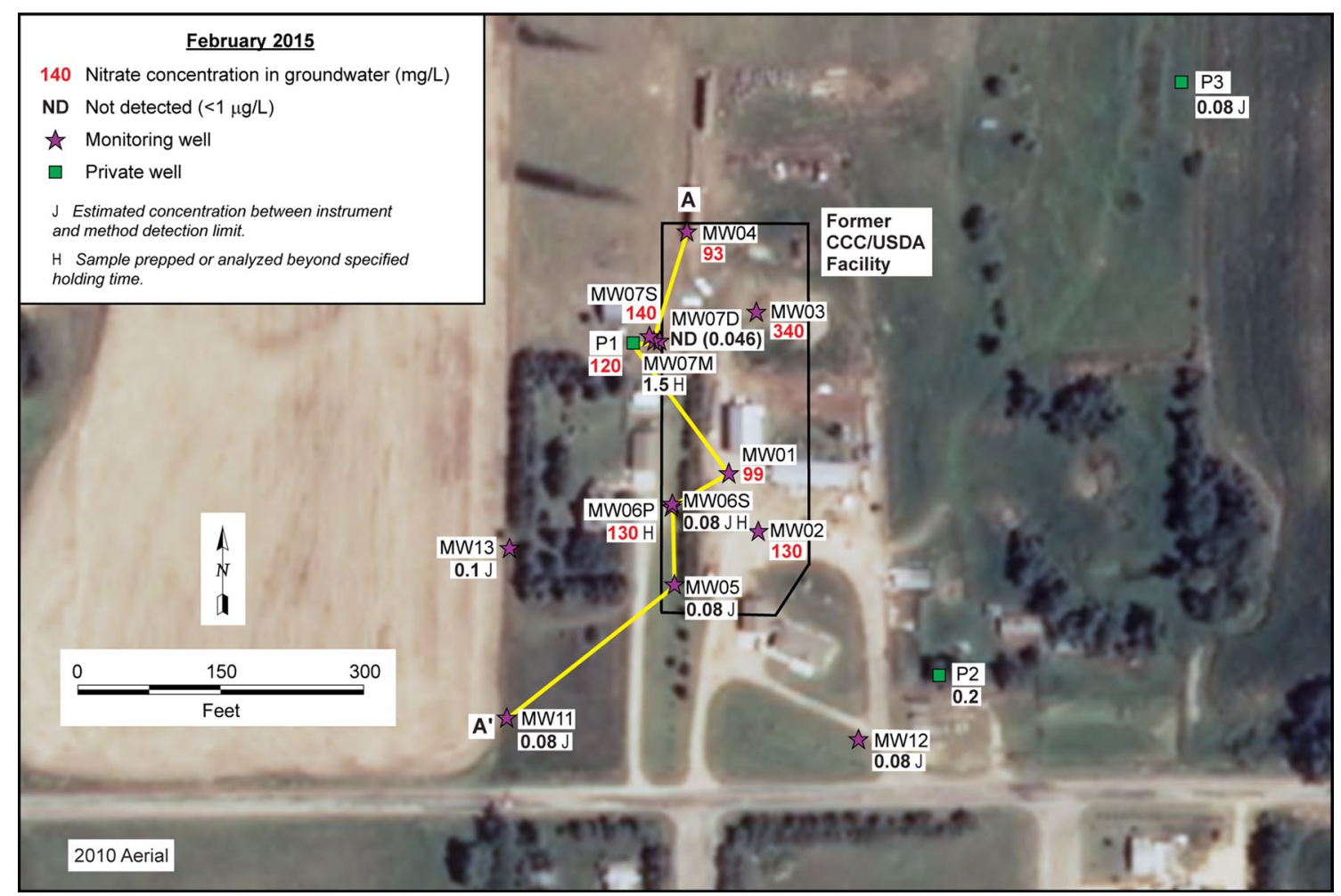

Fig. 6 Nitrate concentrations in the groundwater at the former CCC/USDA facility

water yield from an extraction well was estimated at 0.01 gallons per minute $(\mathrm{gpm})(0.04 \mathrm{~L} / \mathrm{min})$ for the perched aquifer and $0.3 \mathrm{gpm}(1.1 \mathrm{~L} / \mathrm{min})$ for the shallow aquifer. At these extraction rates, the region of influence (ROI) of the extraction well in each of aquifers is estimated based on the area with a drawdown greater than $0.5 \mathrm{ft}(0.15 \mathrm{~m})$, which is computed using Theis equation (Theis 1952) assuming a confined condition over the duration of pumping (Theis 1952). The estimated ROI is $310 \mathrm{ft}(94.5 \mathrm{~m})$ for the perched aquifer and more than $500 \mathrm{ft}(152.4 \mathrm{~m})$ for the shallow aquifer, which is adequate to cover the entire plume with one pumping well in each of the aquifers. The extraction of groundwater would have multiple effects including:

- Directly addressing the contamination present in the perched and shallow aquifers.

- Removing contaminants from the impacted groundwater.

- Facilitating the intrinsic processes that may reduce carbon tetrachloride concentrations to levels approaching the chemical-specific MCL and RBSL value of $5.0 \mu \mathrm{g} / \mathrm{L}$.

The extraction wells will be constructed of 6 in.-diameter schedule 80 polyvinyl chloride with a $10 \mathrm{ft}(3.0 \mathrm{~m})$, \#10 slot high-flow stainless steel screen. Well depths in the perched and shallow aquifer will be $30 \mathrm{ft}$ and $46 \mathrm{ft}(9.1$ and $14.0 \mathrm{~m})$, respectively. The wells will be finished with a 6 -in. cover and lock. Electrical service from the existing electric power infrastructure at the case study site would be dropped to each of the extraction wells or solar-powered extraction pumps would be installed at each of the extraction wells. Influent/effluent pipe transects would be excavated. A standard dimension ratio 11 HDPE 2-in. $(0.05 \mathrm{~m})$ pipe or similar would be installed from the extraction wells to the downstream systems. Submersible pumps (such as a Grundfos RediFlo 3 or similar) and electric service/communication cable would be installed in the extraction wells. The 2-in. $(0.05 \mathrm{~m})$ force main and communication cable would be routed through pitless adaptors and the pipe trench to the downstream treatment systems. A control box, such as the Grundfos CU 300, would be mounted to control, monitor, and display the performance of the pumps.

Two of the most common technologies for the ex situ treatment of extracted groundwater are adsorption by GAC and air stripping. Because of the need to periodically replace the GAC medium, air stripping is the preferred treatment technology. Of the two air stripping designs, tray aeration is preferred because it has a smaller footprint and is better suited for treating the flow rates expected from the extraction well. Although these technologies are well suited to treat carbon tetrachloride, they are not suitable for treating nitrates (present in both the perched and shallow aquifers at concentrations exceeding the MCLs). Any groundwater 
extracted for treatment would likely need also to be treated for nitrates prior to discharge to surface waters so that all MCLs are met.

Based on preliminary bench scale studies, groundwater at the case study site would require two different ex situ unit operations prior to nitrate treatment and another ex situ unit operation after nitrate treatment due to the poor quality (high total hardness and TDS) of groundwater. Extracted groundwater would, therefore, require a pre-filter turbidity reduction system and a water softening system to prepare the water for nitrate treatment. This pre-treated effluent would then be treated by an ion exchange system for nitrate removal. To achieve the nitrate MCL, the ion exchange system would need to be followed up with a reverse osmosis treatment for water polishing. The capital costs for such a multi-component treatment system would be significant. The recurring costs associated with the replenishment of the treatment chemicals for the ion exchange system and containerizing and removing backwash flows from the ion exchange system would also be significant. The highly concentrated backwash water cannot be discharged to the surface and would need to be transported offsite for disposal at a landfill site. Although groundwater extraction and treatment for VOCs only is readily implementable and has moderate costs, groundwater extraction and treatment at the case study site would also need to address nitrate. Nitrate treatment under a conventional remediation scenario would result in additional costs as noted below. In the following section, we propose a low-cost alternative treatment to address both contaminants.

\section{A hybrid phytoremediation system for groundwater extraction and treatment}

One way to address groundwater with a complex mixture of COCs is to use an innovative pairing of two mainstream groundwater remediation technologies. In this case study, we propose pairing groundwater extraction and phytoremediation. For the case study site, we will add a phytoremediation component to replace the ex situ water treatment unit operations (aeration, turbidity removal, ion exchange and reverse osmosis) that would typically be used if we were addressing carbon tetrachloride contamination only. The paired groundwater extraction and phytoremediation system can be designed and operated to achieve the specific remedial action goals of a given project, e.g., achieving drinking water MCLs, the mass removal of contaminants, and the control of contaminant migration.

Groundwater extraction technologies can effectively reduce the mobility and volume of contaminants by coupling groundwater and contaminant removal with the potential for hydraulic control of the contaminant migration patterns near the extraction site. Groundwater extraction is typically accomplished using conventional vertical wells equipped with electrically operated pumps. The depth from which contaminated groundwater can be extracted is only limited by the design limits of the extraction pump (in terms of "head" and flow rate) and the extraction well (in terms of well depth and water yield).

Phytoremediation is capable of treating COCs in several contaminant groups; however, because it is effectively "passive," i.e., it relies on the natural movement of groundwater to the treatment area, such an approach usually results in a prolonged remediation time frame and highly localized effects [e.g., it would not address downgradient contamination or contamination at depths greater than $25 \mathrm{ft}(7.6 \mathrm{~m})]$. In these cases, however, we propose a "modified" phytoremediation approach to actively extract groundwater that would otherwise be inaccessible (because of depth or lateral distance) and route the extracted water to a passive phytoremediation system. This "hybrid" groundwater extractionphytoremediation approach would address contamination that under more conventional approaches would be beyond the influence of the phytoremediation root system alone.

The major components of the groundwater extraction system would be the same as the system previously described and would include submersible pumps, force main piping, and a control box, such as the Grundfos CU 300, to control, monitor, and display the performance of the pumps. Either direct current electrical service powered by a solar array or an alternating current service would be provided for each of the extraction well/water delivery control systems. A solar powered configuration could also be used.

\section{Tree planting component}

The conceptual approach described here is to construct a highly controlled, hybrid phytoremediation system with commercial off-the-shelf technologies. A plant system with high water demand tree species could be flexibly installed at any desired location that can receive contaminated groundwater extracted by vertical wells. Contaminated groundwater would be introduced into the rhizosphere within the confined root cell of each of the trees by means of conventional irrigation system piping. The phytoremediation grove would assist in extracting contaminated groundwater through transpiration and breaking down contaminants by means of root microbial activities.

The number of trees for the phytoremediation system is designed based on the transpiration rate of tree species. Based on the monitoring data from our existing phytoremediation site in the same climate region, we found that the transpiration rate from a normal precipitation year to a wet year increased by $20 \%$ for Eastern cottonwood and $68 \%$ for Niobe Weeping Willow. We expect that an optimal water feeding rate to the root cell of each tree in the 
phytoremediation system can be reached using an automatically controlled irrigation system with a solar-powered weather station and soil moisture sensor placed in the root cell. For the case study site, a phytoremediation grove might consist of 20 trees with the mix of tree species based upon the treatment capacity of the tree-type as determined by design specifications. Trees could be planted in rows. Each tree would be planted according to the conceptual design planting configuration shown in Fig. 7. Trees would be planted in a root cell borehole, measuring $7 \mathrm{ft}(2.1 \mathrm{~m})$ deep and 36 in. $(0.9 \mathrm{~m})$ in diameter. The trees would be planted with a mix of soil amendments including up to one foot of backfill and 1-6 ft (0.3-1.8 m) of organic-rich soil. To ensure that any COCs in the irrigation water (or naturally present in the soil amendments added when planting the trees) do not migrate away from the treatment cell, a contaminant specific treatment layer would be installed at the bottom of the borehole. The contaminant specific treatment layer could include chemical additives or bioaugmentation culture additives which introduce beneficial microorganisms to a site. Such additives are commercially available, including KB 1 from SiREM, (Guelph, Ontario) for example, or hydrogen release compound $\mathrm{HRC}$, available from Regenesis (San Clemente, CA). The ground surface would be textured to divert rainfall away from each tree.

\section{Irrigation control component}

The force main from each extraction well would be routed through pitless adaptors and pipe trenches to irrigation header pipe(s) positioned between rows of trees. The design of a given phytoremediation grove would be dependent on remedial action goals and would be influenced by pounds per square inch and flow rate $(\mathrm{gpm})$ requirements and the number of sprinklers/trees couplets of the design. Irrigation for the hybrid phytoremediation system could be regulated by either a manual or automatic irrigation controller. This conceptual design assumes that the more sophisticated irrigation controller would be used to regulate the distribution of contaminated groundwater to the phytoremediation grove.

The "brain" of the irrigation system is an irrigation controller (see HydroPoint Weather Track website: www. hydropoint.com/products-and-services/weathertrak-etpro3/). The more sophisticated irrigation controllers can control a greater number of separate irrigation zones; they are designed to adjust irrigation flows based on weather changes such as temperature, and rainfall; and they record real-time feedback from rain sensors and moisture sensors. For example, an automatic irrigation controller can be set to automatically shut down irrigation if rainfall is detected or soil moisture exceeds a limit of saturation. In addition, some controllers allow for multiple run/soak cycles with shorter watering periods. Shorter run/soak cycles will preclude the inadvertent escape of groundwater from the root treatment zone.

For conceptual design purposes, it is assumed that a more sophisticated irrigation controller would be used in this hybrid phytoremediation design. In addition to providing better control for the distribution of contaminated groundwater to the phytoremediation grove, these controllers can be interrogated through $\mathrm{WiFi}$ or cell phone links and information on the amount of water extracted and distributed can be obtained for reporting purposes.
Fig. 7 Conceptual design planting configuration

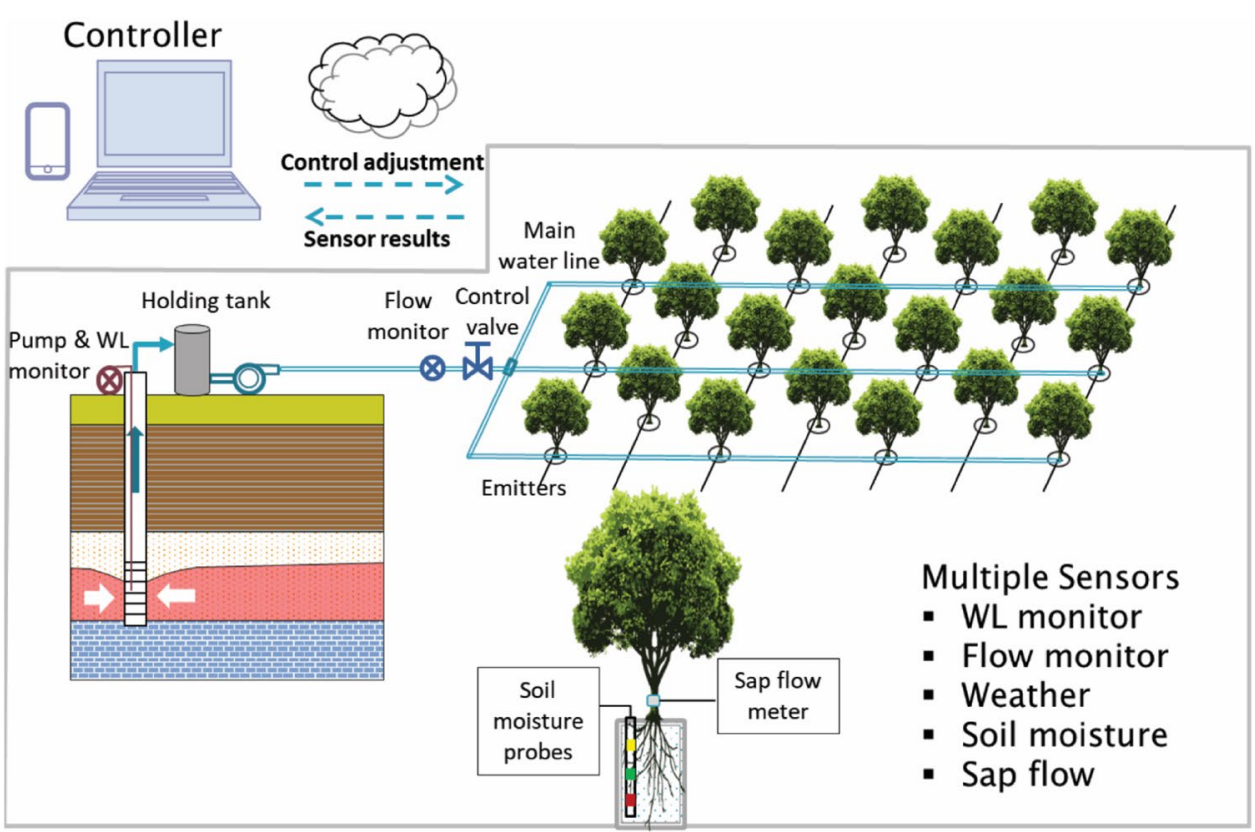


An irrigation controller, such as a HydroPoint WeatherTrak or Rainbird (www.rainbird.com) irrigation controllers or similar, would be installed and configured to control multiple irrigation valve zones. Each irrigation zones might consist of seven to 10 trees, for example (Fig. 7). The water line and low voltage control wires "downstream" from the irrigation controller would be installed in trenches adjacent to the phytoremediation grove. The irrigation controller would measure flow rate, and total flow, as required by groundwater withdrawal regulations.

Extracted groundwater would be pumped into the delivery header pipe as dictated by water level sensor controls in the extraction well. From the header pipe, the irrigation controller would optimize flows to irrigation valves in each zone to provide luxuriant, maximum water required for evapotranspiration of the trees during the growing season. The flow from the irrigation header pipe would be directed into the rhizosphere within the root treatment cell of each of the trees in the phytoremediation grove automatically via properly sized sprinklers such as spot emitters. The system would be designed to pump water to the trees on an as-needed basis as dictated by the delivery controller during the growing season (about 245 day/year) or year-round in the case of evergreen species proposed for the case study site.

\section{Comparison of remedial action costs}

The remedial action costs for the ex situ treatment approach and the phytoremediation approach are summarized in Table 3. The costs noted are for design, administrative burden (permitting), construction, and start-up. No long-term monitoring or operating costs are included in Table 3, but they are discussed below. The elements that each approach have in common are the costs to (1) install two extraction wells; (2) purchase and install two submersible solar-powered pumps and pump cable, pump controller, and pitless adapters; and (3) professional labor management and start-up costs.

The phytoremediation approach includes costs to purchase and install the phytoremediation grove, an irrigation controller, and piping to deliver water to the trees. The ex situ treatment approach includes costs for the purchase and set up of a tray aerator to treat halogenated VOCs and a dual water softener and nitrate system. The ex situ treatment approach would also require the installation of about half of the piping system to deliver water from the extraction wells to the water treatment units (aerator and combined nitrate and ion exchange nitrate treatment systems).

Table 3 Comparison of remedial action costs: Ex situ versus phytoremediation treatment

\begin{tabular}{|c|c|c|c|}
\hline Components of the remedial action construction & Cost $(\$)$ & Ex situ treatment & $\begin{array}{l}\text { Phytore- } \\
\text { mediation } \\
\text { treatment }\end{array}$ \\
\hline Drilling: extraction wells & 38,744 & $\mathrm{x}$ & $X$ \\
\hline Professional labor management (PLM) during drilling & 9907 & $\mathrm{x}$ & $X$ \\
\hline Purchase: two submersible solar powered pumps & 4758 & $\mathrm{x}$ & $\mathrm{X}$ \\
\hline Purchase: pump cable, $8.50 / \mathrm{ft}(28.0 / \mathrm{m})[150 \mathrm{ft}(45.7 \mathrm{~m})$ total $]$ & 2379 & $\mathrm{x}$ & $\mathrm{X}$ \\
\hline Purchase: pump controller & 1909 & $\mathrm{x}$ & $X$ \\
\hline Purchase: water delivery system controller & 1573 & & $X$ \\
\hline Purchase: pitless adapters & 1146 & $\mathrm{x}$ & $\mathrm{X}$ \\
\hline Excavation: $700 \mathrm{ft}(213.4 \mathrm{~m})$ for water delivery piping & 28,511 & & $\mathrm{X}$ \\
\hline Purchase: 2-in. $(0.05 \mathrm{~m})$ high-density polyethylene (HDPE) piping & 3386 & & $\mathrm{X}$ \\
\hline Rental: Bobcat with auger (1 month) & 1889 & & $\mathrm{X}$ \\
\hline Mobilization: phytoremediation, install equipment & 6457 & & $\mathrm{X}$ \\
\hline Demobilization: phytoremediation, install equipment & 6457 & & $X$ \\
\hline Purchase: approximately $20 \times 15$-ft $(4.6 \mathrm{~m})$ trees (phytoremediation) & 3124 & & $\mathrm{X}$ \\
\hline Plant approximately $20 \times 15$-ft $(4.6 \mathrm{~m})$ trees, including cover soil & 2548 & & $\mathrm{X}$ \\
\hline $\begin{array}{l}\text { Start-up, plumbing, power connection, groundwater extraction, and controller } \\
\text { setup }\end{array}$ & 8847 & $\mathrm{x}$ & $\mathrm{x}$ \\
\hline PLM during construction and set up & 14,400 & $\mathrm{x}$ & $\mathrm{x}$ \\
\hline Excavation: $350 \mathrm{ft}(106.7 \mathrm{~m})$ for water piping & 14,255 & $\mathrm{x}$ & \\
\hline Purchase: 2-in. (0.05 m) HDPE piping & 1693 & $\mathrm{x}$ & \\
\hline Purchase: tray aerator & 30,000 & $\mathrm{x}$ & \\
\hline Purchase: dual water softener and nitrate treatment system & 3175 & $\mathrm{x}$ & \\
\hline Total remedial action costs $(\$)$ & & 131,213 & 136,034 \\
\hline
\end{tabular}


As noted in Table 3, the remedial action costs for the two options are similar. And because groundwater treatment remedies take time to work, there would be long-term monitoring costs associated with both approaches. In general, costs for monitoring groundwater should be similar for the two options. The phytoremediation approach does not have a surface water discharge. The surface water discharge for the ex situ treatment approach would likely require periodic monitoring (monthly or quarterly) under requirements of a National Pollutant Discharge Elimination System (NPDES) permit. Ideally, other than groundwater monitoring, no monitoring would be required for the phytoremediation approach. However, there is a possibility that regulatory officials could require expensive monitoring of the phytoremediation grove such as sampling of plant tissue or sap flow monitoring.

The two approaches would have dissimilar long-term operating costs. Both approaches involve similar operating costs for the groundwater extraction component. Irrigation flows for the phytoremediation approach would be automatically controlled by the irrigation control system. In the circumstance of the ex situ treatment approach, backwash from the water softener and nitrate system could not be discharged to surface water. The need to containerize and periodically remove and dispose of backwash from the water softener/ nitrate system could be prohibitively expensive because it involves manpower, trucking, and disposal costs. In addition, the operation of the water softener/nitrate treatment system requires the periodic replenishment of treatment chemicals, adding to the operating costs for the ex situ approach.

\section{Summation}

This paper proposes an approach for extracting and treating contaminant mixtures ex situ using phytoremediation technologies. For the purposes of this paper, a specific case study was described wherein conventional groundwater remediation technologies and phytoremediation approaches have been compared and contrasted with a hybrid phytoremediation system. Nitrate is used as an exemplar co-contaminant in the mixture since nitrate contamination is widespread in the United States and since nitrates are difficult and expensive to treat. This hybrid active/passive phytoremediation approach would involve using contaminated groundwater as a source of irrigation water for a phytoremediation system, such as a phytoremediation grove. Unlike the situation with conventional phytoremediation systems, the phytoremediation grove would not have to be planted immediately above contaminated groundwater. Groundwater would be extracted using conventional well installation and groundwater extraction methods. Groundwater would then be pumped to an automatic irrigation controller which regulates the flow of water to multiple irrigation zones established in a desired location. Each zone would consist of a number of trees. The root system for each tree would be modified to function as a confined treatment cell that facilitates (a) contaminated water uptake to support transpiration and degradation through plant tissues, and (b) microbial activities to breakdown the remaining contaminants within the cell. Extracted groundwater could be provided to each of the root treatment cells in the phytoremediation system directly during the growing season (for woody annuals) or year-round (for evergreen species) via subsurface irrigation.

Acknowledgements Work supported by the Commodity Credit Corporation, US Department of Agriculture, under an interagency agreement with the US Department of Energy. The submitted manuscript was created by the UChicago Argonne, LLC, Operator of Argonne National Laboratory ("Argonne"). Argonne, a US Department of Energy Office of Science laboratory, is operated under US Department of Energy Contract no. DE-AC02-06CH11357. The US Government retains for itself, and others acting on its behalf, a paid-up nonexclusive, irrevocable worldwide license in said article to reproduce, prepare derivative works, distribute copies to the public, and perform publicly and display publicly, by or on behalf of the Government. The Department of Energy will provide public access to these results of federally sponsored research in accordance with the DOE Public Access Plan.

Open Access This article is distributed under the terms of the Creative Commons Attribution 4.0 International License (http://creativeco mmons.org/licenses/by/4.0/), which permits unrestricted use, distribution, and reproduction in any medium, provided you give appropriate credit to the original author(s) and the source, provide a link to the Creative Commons license, and indicate if changes were made.

\section{References}

Anderson TA, Walton BT (1995) Comparative fate of $\left[{ }^{14} \mathrm{C}\right]$ trichloroethylene in the root zone of plants from a former solvent disposal site. Environ Toxicol Chem 14(12):2041-2048

Anderson TA, Guthrie EA, Walton BT (1993) Bioremediation in the rhizosphere. Environ Sci Technol 27(13):2630-2636

Argonne (2009) Summary of operations and performance of the Murdock site restoration project in 2008, ANL/EVS/AGEM/ TR-09-06, prepared for the Commodity Credit Corporation, US Department of Agriculture, Washington, DC by Argonne National Laboratory, Argonne, IL, June

Brigmon RL, Anderson TA, Fliermans CB (1999) Methanotrophic bacteria in the rhizosphere of trichloroethylene degrading plants. Int J Phytoremediat 1(3):241-253

Davis UC, Jacobs JB (2012) Drinking water treatment for nitrate: addressing nitrate in California's drinking water, with a focus on Tulare Lake Basin and Salinas Valley groundwater, Technical Report 6, prepared for the "State Water Resources Control Board Report to the Legislature" by The University of California at Davis and Jacobs Engineering Group, Inc., Pasadena, CA, March

Davis LC, Lupher D, Hu J, Erickson LE (1999) Transport of trichlorethylene through living plant tissues. In: Erickson LE, Rankin MM (eds) Proceedings of the 1999 Conference on Hazardous Waste Research. Agency Great Plains/Rocky Mountains Hazardous Substance Research Center, Kansas State University, Manhattan, Kansas 
DiSimone LA, McMahon PB, Rosen MR (2014) The quality of our nation's water-water quality in principal aquifers of the United States, 1991-2010. National Water-Quality Assessment Program, Circular 1360, US Geological Survey, Reston

Dubrovsky NM, Burow KR, Clark GM, Gronberg JM, Hamilton PA, Hitt KJ, Mueller DK, Munn MD, Nolan BT, Puckett LJ, Rupert MG, Short TM, Spahr NE, Sprague LA, Wilber WG (2010) The quality of our nation's water-nutrients in the nation's streams and groundwater, 1992-2004. National Water-Quality Assessment Program, Circular 1350, US Geological Survey, Reston, VA

FRTR (2002) Remediation technologies screening matrix and reference guide. Version 4.0, prepared by the Federal Remediation Technology Roundtable, January. https://frtr.gov. Accessed 16 July 2019

Healy J (2018) Rural America's own private flint: polluted water too dangerous to drink, article in The New York Times, November 3

ITRC (2003) Technical and regulatory guidance document for constructed treatment wetlands. Interstate Technology Regulatory Council, December

ITRC (2009) Phytotechnology technical and regulatory guidance and decision trees, revised. PHYTO-3, Interstate Technology Regulatory Council, February

Jacobs JB, Davis UC (2011) An assessment of the state of nitrate treatment alternatives. Final Report, prepared by Jacobs Engineering Group, Inc., Pasadena, California, and The University of California at Davis, for the Inorganic Contaminant Research and Inorganic Water Quality Joint Project Committees, American Water Works Association, June

Jasper JT, Jones ZL, Sharp JO, Sedlak DL (2014) Nitrate removal in shallow, open-water treatment wetlands. Environ Sci Technol 48(19):11512-11520

Misiorowski M, Eagle JD (2007) A well of a program: the legacy of carbon tetrachloride in US groundwater. The Bureau of National Affairs, Inc. Daily Environment Report 2007, no. 227, November 27

Newman LA, Strand SE, Choe N, Duffy J, Ekuan G, Ruszaj M, Shurtleff BB, Wilmoth J, Heilman P, Gordon MP (1997) Uptake and biotransformation of trichloroethylene by hybrid poplars. Environ Sci Technol 31(4):1062-1067

Newman LA, Wang X, Muiznieks IA, Ekuan G, Ruzaj M, Cortelucci R, Domroes D, Karscig G, Newman T, Crampton RS, Hasmonay RA, Yost M, Heilman PE, Duffy J, Gordon MP, Strand SE (1999) Remediation of trichloroethylene in an artificial aquifer with trees: a controlled field study. Environ Sci Technol 33(13):2257-2265
Schechinger AW, Cox C (2018) America's nitrate problem is costly and dangerous, prevention is the solution, but voluntary actions fall short, Environmental Working Group, October 2. https://www. ewg.org/research/nitratecost/. Accessed 16 July 2019

Theis CV (1952) The relation between the lowering of the piezometric surface and the rate and duration of discharge of a well using groundwater storage. In: American Geophysical Union transactions 16th annual meeting. pp 519-524

US Census Bureau (2019) 2020 census research, operational plans, and oversights. https://www.census.gov/programs-surveys/decen nial-census/2020-census.html. Accessed 16 July 2019

USDA (2009) Chapter 3: constructed wetlands, in Part 637 Environmental Engineering, National Engineering Handbook, Natural Resources Conservation Service, US Department of Agriculture, November

USEPA (2005) Use of field-scale phytotechnology for chlorinated solvents, metals, explosives and propellants, and pesticides. EPA 542-R-05-002, Office of Solid Waste and Emergency Response, US Environmental Protection Agency, Washington, DC, April

USEPA (2006) Process design manual land treatment of municipal wastewater effluents. EPA/625/R-06/016, Office of Research and Development, US Environmental Protection Agency, Cincinnati, Ohio, September

USEPA (2010) Phytotechnologies for site cleanup. EPA 542-F-10-009, Office of Remediation and Technology Innovation, US Environmental Protection Agency, Washington, DC, September

USEPA (2016) Contaminated site clean-up information (CLU-IN), phytotechnology project profiles. Technology Innovation and Field Services Division, US Environmental Protection Agency, Washington, DC. https://cluin.org/products/phyto/. Accessed 31 Jan 2019

USEPA (2019) Estimated nitrate concentrations in groundwater used for drinking. US Environmental Protection Agency. https://www. epa.gov/nutrient-policy-data/estimated-nitrate-concentrationsgroundwater-used-drinking. Accessed 16 July 2019

Wang X, Dossett MP, Gordon MP, Strand SE (2004) Fate of carbon tetrachloride during phytoremediation with poplar under controlled field conditions. Environ Sci Technol 38(21):5744-5749

Publisher's Note Springer Nature remains neutral with regard to jurisdictional claims in published maps and institutional affiliations. 